\title{
Chemical characterization of almond meal as a co-product of the mechanical extraction of almond oil.
}

\author{
Nadia Houmy ${ }^{1,5^{*}}$, Reda Melhaoui ${ }^{1}$, Kamal Belhaj ${ }^{1}$, Aurore Richel ${ }^{2}$, Marianne Sindic ${ }^{3}$, \\ Christophe Hano ${ }^{4}$, Souhayla Kodad ${ }^{1}$, Aatika Mihamou ${ }^{1}$,Mohamed Addi ${ }^{1}$, Malika Abid ${ }^{1}$ and \\ Ahmed Elamrani ${ }^{1}$. \\ ${ }^{1}$ Laboratory for Agricultural Productions Improvement, Biotechnology and Environment, Faculty of \\ Sciences, University of Mohammed Premier, Oujda, Morocco \\ ${ }^{2}$ Laboratory of Biological and Industrial Chemistry, University of Liège, Gembloux, Belgium \\ ${ }^{3}$ Laboratory QSPA, Gembloux Agro Bio Tech, University of Liège, Gembloux, Belgium \\ ${ }^{4}$ Laboratoire de Biologie des Ligneux et des Grandes Cultures, OrleansUniversity, \\ France \\ ${ }^{5}$ Laboratory of Food Technology and Quality, CRRA, INRA, Oujda, Morocco.
}

\begin{abstract}
Almonds harvesting, along with precleaning, hulling, shelling, and sorting, generate recoverable co-products such as double, malformed, or damaged almonds. The common way that generates more benefit is the extraction of almond oil for food and cosmetic uses. The aim of this study is to compare composition and nutritional value of almond meals of the main varieties from eastern Morocco, Marcona (M), Fournat de Breznaud (FNB), FerragnesandFerraduel (FF) and Beldi a local ecotype (B), during three consecutive crop years (2016-2018). Significant differences were observed, which mainly concern the residual oil in almond cakes and especially their fibres, sugars, and proteins. Differences depend on the quality of the raw material and the effects of the crop year on the variety. Besides, from a nutritional point of view, analysed almond meals still contain significant amounts of residual oil and the major constituents of almond seeds (sugars, fibres, and proteins). The amino acid profile presents eight essential amino acids (Cysteine, Methionine, Isoleucine, Leucine, Phenylalanine, Tyrosine, and Lysine Valine) and the Protein Digestibility Corrected Amino Acid Score (PDCAAS) ranges between $24.78 \%$ for $(\mathrm{M})$ and $62.17 \%$ for $(\mathrm{FF})$. We conclude the analysed almond meals present interesting nutritional values as a specific ingredient for gluten-free culinary preparations and light foodstuffs.
\end{abstract}

\section{Introduction}

Almonds are the edible seeds of the Prunus amygdalus Dulcis tree, more commonly known as the almond tree, which is native from its wild ancestors of the central plateau of Asia, currently domesticated, and widely cultivated in Mediterranean climate areas [1]. Although

\footnotetext{
Corresponding author:houmy.nadia@gmail.com
} 
almonds are commonly referred to as nuts, they are actually the seeds found at the centre of the almond fruit. Almond fruit consists of four parts: kernel or Seed or "meat", seed coat (a thin leathery layer known as brown skin of the seed), almond shell, and almond hull which corresponds to the outer green shell cover [2].

The kernel or seed is the edible part of the nut, with a high nutritional value. Almond kernels can be consumed raw or cooked, blanched, ground into flour and even made into non-dairy milk. It can be also incorporated, as an ingredient, into culinary recipes. They are very rich in fat, making them a perfect source of edible oil and oil for cosmetic [3].

In eastern Morocco, thanks to the Moroccan green plan and the PROFAO (Solidarity farming Project of Almond Sector in Eastern Morocco, 2011-2018); 6000 hectares of new almond orchards were created. PROFAO, as an integrated project, allows the organisation of almond's farmer cooperatives and facilitates the creation of economic interest grouping for almond post-harvest facilities, processing, production and marketing of almonds and derivatives [4].

Almond nuts crushing, shelling and sorting operations generate co-products like doubles malformed almonds or mechanically damaged (split and broken kernels) and defects seeds. The best way for exploiting this co-product and deriving more benefits and add value is the mechanical extraction of almond oil for food and cosmetic uses. This process of almond oil extraction also generates another by-product (Almond residue or almond meal) which represents at least $50 \%$ by gross mass of the raw material of damaged almonds. Thus, the aim of this study is to assess the nutritional value of these almond residues by analysing the chemical composition of almond meals from fourintroduced varieties, Marcona (M), Fournat de Breznaud(FNB), FerragnesandFerraduel(FF) and Beldi a local ecotype (B), during three consecutive crop years (CY1: 2016; CY2: 2017; CY3: 2018).

\section{Material and methods}

\subsection{Plant material and sampling}

In eastern Morocco, producers and processors of almonds in the Sidi Bouhria region are organised into an economic interest grouping (GIE- Sidi Bouhria). In order to derive maximum benefit from their almond production with the perspective of zero waste and using everything the almonds orchard grows. Thus, the almond kernels grading and sorting co-product, corresponding to split \& broken malformed and double almonds, is intended for the extraction of almond oil for food and cosmetics. In addition to almond oil, the mechanical process produces a residue "the almond cake /"meal". This study concerns the chemical characterisation of the almond meals of the five most cultivated varieties in the region of eastern Morocco. The almonds come from five-year-old almond trees, installed on a limestone soil located in Sidi Bouhria, in the east of Morocco (GPS coordinates: $34^{\circ}$ $\left.44^{\prime} 13.6^{\prime \prime} \mathrm{N}, 002^{\circ} 20^{\prime} 15.0^{\prime \prime} \mathrm{W}\right)$. The orchards are rain-fed with a minimum of additional irrigation under semi-arid climatic conditions (Table 1). The GIE-Sidi-Bouhria provided the almond meals used in this study.

Table 1. The average temperature and annual cumulated precipitation registered at the closest meteorological station to Sidi Bouhria region (GPS coordinates: $34^{\circ} 44^{\prime} 13.6^{\prime \prime} \mathrm{N}$, $002^{\circ} 20^{\prime} 15.0^{\prime \prime} \mathrm{W}$ ) during the three crop years (CY) 2016-2018

\begin{tabular}{|c|c|c|c|}
\hline \multirow{2}{*}{$\begin{array}{c}\text { Sidi Bouhria } \\
\text { crop year }\end{array}$} & \multicolumn{2}{|c|}{ Average temperature $\left({ }^{\circ} \mathrm{C}\right)$} & $\begin{array}{c}\text { Annual cumulated } \\
\text { precipitation }(\mathrm{mm})\end{array}$ \\
\cline { 2 - 3 } & Minimum & Maximum & 289.6 \\
\hline CY1 $(2016)$ & 11.5 & 24.5 & 231.5 \\
\hline CY2 $(2017)$ & 12.5 & 25.6 & 205.4 \\
\hline CY3 $(2018)$ & 12 & 26.0 & \\
\hline
\end{tabular}




\subsection{Mechanical extraction of almond oil}

The mechanical extraction of almond oil was carried out by a mechanical press system (IBG MonfortsOekotec $\mathrm{GmbH} \& \mathrm{Co.KG}$, made in Germany). The screw speed was 60 RPM, and the fine particles were removed from the almond oil by filtration followed by centrifugation at $3000 \mathrm{RPM}$ for $15 \mathrm{~min}$. The GIE-Sidi Bouhria provided almond meal samples for the Physico-chemical analyses. Samples were crushed and sieved through a 1 $\mathrm{mm}$ mesh sieve, then stored at $4^{\circ} \mathrm{C}$ until use. Analyses were made in triplicate for the almond meal of each variety.

\subsection{Physico-chemical analyses}

\subsubsection{Dry matter}

Dry matterwas carried out in accordance with the thermogravimetric method [5]. It consists to dry 5 to $20 \mathrm{~g}$ of the homogenized sample at $103^{\circ} \pm 2^{\circ} \mathrm{C}$ until obtaining a constant weight.

\subsubsection{Residual oil}

Residual oil in almond meal of deferent varieties was performed by chemical extraction using a Soxhlet apparatus, where $200 \mathrm{ml}$ of hexane was used for a total oil extraction of $5 \mathrm{~g}$ of powdered almond meal then the solvent was evaporated under vacuum using a rotary evaporator and the oil was collected [6].

\subsubsection{Total sugars}

Total sugars contentsis determined according to the Bertrand method with little modifications in four main steps:The first step performed by acid hydrolysis and neutralization of the entire hydrolysate to transform all the polysaccharides into simple reducing sugars. The second step is a sample deproteinisation. The third step consistinto precipitation and filtrationof sugars extract. Finally, titration with potassium permanganate was carried out for determination of total sugar contents in analysed samples of almond meal. The result is expressed as a percentage of mass of glucose in $100 \mathrm{~g}$ of sample [7].

\subsubsection{Dietary fibres}

The determination of dietary fibreswas carried out according to the AOAC 991 method [8]. Three successive enzymatic attacks were carried out ( $\alpha$-amylase, protease and $\alpha$ amyloglucosidase) to eliminate starch and proteins. The fibresare precipitated by technical ethanol. The obtained value was corrected by determining the residual ash (Muffle furnace), proteins (Kjeldahl) and by the blank.

\subsubsection{Ash}

Ash is determined according to the AACC 2001method [9]. The aim is to determine the mineral content of the sample by heating and so destroying the organic material. Thus, $5 \mathrm{~g}$ of the already dried sample was introduced in a pre-tared crucible. Then the sample was introduced into a Muffle furnace at $550{ }^{\circ} \mathrm{C}$ overnight, then allowed to cool in a desiccator and finally the weight difference was measured. 


\subsubsection{Proteins}

Total nitrogen content was estimated by the Kjeldahl method [10], then protein content was calculated by multiplying the total nitrogen content by a conversion factor of 5.18 [11].

\subsubsection{Amino acid profiles}

The determination of amino acids by HPLC is carried out according to the method of Spackman et al., [12] by acid hydrolysis of almond meal proteins. This analysis depends on the protein content in sample (500 mg for a sample containing $2 \%$ of nitrogen). In our case, $130 \mathrm{mg}$ of each almond meal sample was taken and dissolved in $10 \mathrm{ml}$ of $6 \mathrm{~N}-\mathrm{HCl}$ containing $0.1 \%$ phenol. The samples were mixed and sealed in the presence of nitrogen, and then were heated in oven at $110^{\circ} \mathrm{C}$ for 24 hours. After cooling in ice, a solution of 30 $\mathrm{ml}$ of a citrate buffer at $\mathrm{pH} 2.2$ was added, then a $\mathrm{pH}$ adjustment was carried out with $7.5 \mathrm{~N}$ and $1 \mathrm{~N}$ of $\mathrm{NaOH}$ respectively in order to obtain a $\mathrm{pH}$ of 2.2. The solutions thus obtained were diluted with citrate buffer $(\mathrm{pH}=2.2)$, after adding $1 \mathrm{ml}$ of Norleucine at $50 \mu \mathrm{M} / \mathrm{ml}$ as internal standard. The solutions were partially filtered by $0.2 \mu \mathrm{m}$ filter. A $20-\mu \mathrm{l}$ of aliquot was injected into the HPLC using a sodium oxidase column, cation exchange resin, a column post for the derivation of amino acids into ninhydrin and a UV detector at $570 \mathrm{~nm}$ except for Proline at one length $440 \mathrm{~nm}$ wave.

\subsubsection{Protein quality calculations}

The protein quality evaluation was studied by calculation of sum essential amino acid ( $\Sigma$ EAA), sum of non-essential amino acid ( $\Sigma$ NEAA) (indicate the importance of the nutritional value of proteins), Chemical Index (CI) and Proteins Digestibility of Corrected Amino Acid Score (PDCAAS). This later has been adopted as the chosen method for the measurement of the protein value in human nutrition [13].

The Chemical Index (CI) was calculated on the basis of the procedure described previously by Sujak et al (2006), based on following calculation[(\% limiting amino acid $\left.\left.)_{\text {sample }} /(\% \text { limiting amino acid })_{\text {protein of reference }}\right)\right]$ x100 [14]. In our case, limiting amino acidswere Met + Cys and the protein referenceused of amino acids forhuman food protein composition appropriate for an adult human was $\mathrm{FAO} / \mathrm{WHO} / \mathrm{UNU}$ requirements(2007) (Table 2) [13].

Table 2. Protein of reference from $\mathrm{FAO} / \mathrm{WHO} / \mathrm{UNU}$

\begin{tabular}{|l|l|}
\hline Essential amino acids & $\% \mathrm{AA}$ \\
\hline Cysteine + Methionine & 1.7 \\
\hline Histidine & 1.6 \\
\hline Isoleucine & 1.3 \\
\hline Leucine & 1.9 \\
\hline Lysine & 1.6 \\
\hline Phenylalanine + tyrosine & 1.9 \\
\hline Threonine & 0.9 \\
\hline Tryptophan & 0.5 \\
\hline Valine & 1.3 \\
\hline Sum of EAA & 12.7 \\
\hline
\end{tabular}

AA: amino acid ( $\mathrm{g}$ of $100 \mathrm{~g}$ of protein) 
Protein digestibility Corrected Amino Acid Score (PDCAAS) was determined according to Schaafsma [15], where it is CI $\times$ true faecal digestibility of almond meal. The true faecal digestibility in our study was used from Ahrens et al (2005) results [16].

\subsection{Statistical analysis}

The chemical characterization of almond meal obtained from four varieties and one local ecotype, during three consecutive crop years, was carried out on triplicate for each sample and each parameter. Statistical analyses were conducted using Statistical Package for the Social Sciences (SPSS for Windows, version 21, SPSS Inc., Chicago, IL, USA). The normal distribution was verified according to Shapiro Wilk test. Two-way ANOVA statistical analysis and Tuckey's post-hoc test was used for means comparison, the difference was considered significant (at $P<0.05$ ).

\section{Results and discussion}

Almond processing coproducts might represent a precious source of raw materials for food, cosmetic, and pharmaceutical industries, however, their valorisation needs a fine physicochemical characterization for the development of novel procedures to be implemented to the sectorial industries. Indeed, providing innovative products from Almond pressed-oil residues (communally named almond oilcake or almond meal) could provide benefit to the overall almond production. Table 3 shows chemical composition of almond meals, corresponding to almond pressed-oil residue, of five most cultivated varieties in the regions of eastern Morocco [Marcona (M), Fournat de Breznaud (FNB), Ferragnes and Ferraduel (FF) and the Beldi (B)]. These results (table 3) concern three consecutive crop years and six analysed parameters of Almond meals: dry matter, residual oil, sugars, fibres, ash andproteins contents.In general, the chemical composition of almond oil meal change between varieties and crop years mainly for dry matter, sugars and ash.

\subsection{Dry matter}

Dry matter data registered for almond meals (Table 3), range between a minimum of $89.29 \%$ for FF-CY1 and a maximum of $94.56 \%$ for M-CY2. Indeed, dry matter values for analysed almond meals of each varieties are slightly different; these differences seem to be mainly related to the harvest year, the variety, and probably to the technique of post-harvest drying. The ANOVA analysis (Table 3) confirms this observation and shows a significant difference at $P<0.05$. In general, the results are similar to the literature, for instance, Arbouche R (2013) found 94.6\% dry matter in the almond meal [17], which is very similar to our findings for M-CY2 $(94.56 \%)$. These results are comparable to those of several other types of meals (oil cakes of soybean, groundnut, coconut, cottonseed, sunflower, sesame), whose dry matter contents vary between $85 \%$ to $94 \%$ [18].

\subsection{Residual oil}

Oil cakes/meals are solid residues, obtained after the extraction of oil from the plant part such as seeds or nuts. In general, residual oil in meals depends on quality of the raw material and on the processing of oil extraction. In spite of the fact that the process used for extraction of almond oils is the same for all varieties, the quantities of residual oil extracted from different almond meals analysed (Table 3 ) vary widely between a minimum of $7.45 \%$ (M -CY1) to a maximum of $23.58 \%$ (M-CY2). F-F and FNB present the highest residual oil content comparing to (M) and (B). The ANOVA analysis (Table 4) confirms this observation and shows a significant difference at $P<0.001$. Since the press system is the same, the difference should be related to the raw material, particularly to the physical state 
of the kernels, moisture and kernels defects but also to the almonds variety [19]. In this regard, Rabadan et al (2017) reported comparable results that range from $15.24 \%$ and 25.5 $\%$ of residual oil in almond meals[20] and his concluded that residual oil of meals depends on efficiency of mechanical oil extraction. Besides, Savoire et al. (2013) reported that residual oil yield was influenced by many parameters such as kernels variety; press system parameters and pre-treatments preceded this process [21].

\subsection{Sugars}

Whatever the crop year,almond oil cake of the variety Marcona (M) had the lowest sugar content (Table 3)respectively for the three studied years $(12.60 \% ; 12.57 \% ; 15.02 \%)$, while the variety Fournat(FNB) seems to present the highest sugar content $(13.84 / 21.65 \%$ / $19.21 \%$ ). The sugar contents of almond oil meals from the three other varieties are between these limit values. It is certainly here genotype-related differences, which are confirmed by ANOVA analysis (Table 4) that shows significant differences between genotypes at $P<0.05$.

The almond oil cake, although considered simply as a by-product of almond oil extraction, is an excellent source of nutrients such as proteins, vitamins, minerals, fibres and bioactive components that may offer a number of health benefits. In this regard recently, in a research collaboration, but also from the literature [22-25], we show that high phenolic content remains in this coproduct making it usable for improvement of nutritional and functional properties of certain food products. In addition, this coproduct contains significant amounts of other phytochemicals compounds including tocopherols, flavonoids, tannins, and can be used for cosmetics and pharmaceutical purposes.

In the present study, analyses focus on proteins content, amino acids profile ash and dietary fibres.

\subsection{Dietary fibers and Ash}

Dietary fibres can act by changing the nature of the contents of the gastrointestinal tract and by changing how other nutrients and chemicals are absorbed. Fibres and minerals bring nutritional benefits to consumers. The results of the analysed almond cakes for the dietary fibres and ash contents are presented in Table 3. They vary between a minimum of $31.52 \%$ /DM registered for Marcona (M-CY2) and a maximum of 42.3\%/ DM for Beldi ecotype (B-CY2). The calculated average value of dietary fibres content in analysed almond meals is $35.5 \%$ / DM for the three crop years of this study, this value is in accordance with the literature.

Analysis of ANOVA (Table 4) show no significant difference for the factor Year, whereas the factors Variety and Year * Variety interaction present a significant difference between the samples at $P<0.05$. Finally, the fibres' content of analysed almond meals is clearly higher than those given, by the literature, such as those of sunflower seeds $(28.41 \%)$ and soybean (17.8\%) [19]. 
Table 3.Summary of chemical compositions of almond mealfrom five most cultivated varieties in eastern Morocco. Results of analyses concern almond meal contents (\%) for :dry matter, residual oil, sugars and fibres contents, ash, proteins content and amino acid profile for three consecutive crop years (CY: Crop year; M: Marcona: FNB: Fournat de Breznaud; FF: Ferragnes - Ferraduel; B: Beldi)

\begin{tabular}{ccccccc}
\hline Sample & Dry matter \% & Residual oil \% & Sugars \% & Dietary fibres \% & Ash \% \\
\hline M-CY1 & $90.44 \pm 0.40 \mathrm{ab}$ & $7.45 \pm 0.20 \mathrm{a}$ & $12.60 \pm 0.64 \mathrm{a}$ & $33.04 \pm 2.43 \mathrm{a}$ & $7.28 \pm 0.00 \mathrm{e}$ & $43.24 \pm 5.38 \mathrm{e}$ \\
FNB-CY1 & $91.51 \pm 0.19 \mathrm{~b}$ & $7.66 \pm 0.30 \mathrm{a}$ & $13.84 \pm 0.20 \mathrm{a}$ & $32.26 \pm 2.93 \mathrm{a}$ & $7.14 \pm 0.01 \mathrm{e}$ & $39.58 \pm 0.34 \mathrm{de}$ \\
F-F-CY1 & $89.29 \pm 1.70 \mathrm{a}$ & $8.52 \pm 0.55 \mathrm{ab}$ & $13.74 \pm 0.28 \mathrm{a}$ & $37.71 \pm 3.36 \mathrm{ab}$ & $8.03 \pm 0.08 \mathrm{fg}$ & $37.59 \pm 0.34 \mathrm{bcd}$ \\
B-CY1 & $91.16 \pm 0.25 \mathrm{~b}$ & $8.07 \pm 0.35 \mathrm{ab}$ & $14.20 \pm 0.99 \mathrm{a}$ & $34.86 \pm 2.56 \mathrm{ab}$ & $7.89 \pm 0.10 \mathrm{f}$ & $38.79 \pm 0.21 \mathrm{~cd}$ \\
M-CY2 & $94.56 \pm 1.19 \mathrm{~d}$ & $23.58 \pm 1.22 \mathrm{f}$ & $12.57 \pm 0.71 \mathrm{a}$ & $31.52 \pm 5.04 \mathrm{a}$ & $6.80 \pm 0.06 \mathrm{~d}$ & $34.79 \pm 2.80 \mathrm{abc}$ \\
FNB-CY2 & $93.37 \pm 0.63 \mathrm{~d}$ & $12.17 \pm 0.56 \mathrm{~cd}$ & $21.65 \pm 0.32 \mathrm{~d}$ & $38.42 \pm 3.97 \mathrm{ab}$ & $8.15 \pm 0.11 \mathrm{~g}$ & $31.15 \pm 0.13 \mathrm{a}$ \\
F-F-CY2 & $94.06 \pm 0.88 \mathrm{~d}$ & $22.48 \pm 1.03 \mathrm{e}$ & $14.48 \pm 0.85 \mathrm{ab}$ & $31.94 \pm 2.93 \mathrm{a}$ & $6.84 \pm 0.03 \mathrm{~d}$ & $33.39 \pm 0.01 \mathrm{ab}$ \\
B-CY2 & $93.23 \pm 0.98 \mathrm{~cd}$ & $8.71 \pm 0.65 \mathrm{ab}$ & $18.85 \pm 2.90 \mathrm{~cd}$ & $42.30 \pm 1.58 \mathrm{~b}$ & $7.98 \pm 0.03 \mathrm{fg}$ & $38.78 \pm 0.24 \mathrm{~cd}$ \\
M-CY3 & $93.55 \pm 6.44 \mathrm{~d}$ & $8.95 \pm 0.84 \mathrm{~b}$ & $15.02 \pm 1.30 \mathrm{ab}$ & $35.45 \pm 2.13 \mathrm{ab}$ & $4.75 \pm 0.01 \mathrm{a}$ & $36.61 \pm 1.05 \mathrm{bcd}$ \\
FNB-CY3 & $91.80 \pm 8.22 \mathrm{bc}$ & $12.81 \pm 0.38 \mathrm{e}$ & $19.21 \pm 0.55 \mathrm{~cd}$ & $39.75 \pm 0.51 \mathrm{ab}$ & $7.25 \pm 0.03 \mathrm{e}$ & $36.54 \pm 0.12 \mathrm{bcd}$ \\
F-F-CY3 & $90.74 \pm 9.26 \mathrm{ab}$ & $11.9 \pm 0.11 \mathrm{~cd}$ & $15.29 \pm 0.44 \mathrm{ab}$ & $34.50 \pm 0.56 \mathrm{ab}$ & $5.88 \pm 0.05 \mathrm{~b}$ & $40.18 \pm 1.13 \mathrm{de}$ \\
B-CY3 & $91.85 \pm 8.15 \mathrm{bc}$ & $10.41 \pm 0.09 \mathrm{c}$ & $17.48 \pm 0.97 \mathrm{bc}$ & $35.05 \pm 2.39 \mathrm{ab}$ & $6.14 \pm 0.12 \mathrm{c}$ & $36.50 \pm 0.26 \mathrm{bcd}$ \\
\hline
\end{tabular}


Ash contents of the analysed almond meals from the three crop years (Table 3) varied between a minimum of $4.75 \%$ DM for (M-CY3) and $8.15 \%$ DM for (FNB-CY2). Analysis of ANOVA (Table 4) shows that there is a significant difference between the analysed samples at $P<0.05$. However, the observed differences can not be related to almond genotype or crop year effect. Almond meal is rich in macro elements, namely, potassium, phosphorus and magnesium (data not shown) which make it an important source of these essential elementsRabadan et al. (2017) [20]. In this regard, Karaman et al (2015), recommend, whenever possible, to incorporate a low dose (1 to $2 \%$ ) of almond flour in food products (for instance baked goods) to improve their nutritional quality and enrich their mineral content[24].

Table 4. Variance Analyses "ANOVA two way" of constituents of almond cake/ meal, from five most cultivated varieties in eastern Morocco (NS=Non-significant,,+++ and +++ stand for significate difference at $0.05,0.01$ and 0.001 respectively

\begin{tabular}{|l|l|l|l|l|l|l|}
\hline & $\begin{array}{l}\text { Dry } \\
\text { matter }\end{array}$ & $\begin{array}{l}\text { Residual } \\
\text { oil }\end{array}$ & Sugars & $\begin{array}{l}\text { Dietary } \\
\text { fibres }\end{array}$ & Ash & Proteins \\
\hline Year & +++ & +++ & +++ & NS & +++ & +++ \\
\hline Variety & +++ & ++ & +++ & + & +++ & ++ \\
\hline Year*Variety & +++ & +++ & +++ & ++ & +++ & +++ \\
\hline
\end{tabular}

\subsection{Protein content and amino acid profiles of almond oil cake}

The growing interest in almonds and derivatives is due to their nutritious ingredients such as lipids, proteins, carbohydrates, vitamins and minerals, as well as secondary metabolites. Most studies focus on almond oil, for food uses and especially in cosmetics, that is more profitable, however, few studies concern the protein fraction, which after almond oil extraction constitutes the major component of the almond cake / meal. According to US department of agriculture (USDA) database, the protein content ranges from 16.0 to $22.0 \%$ of kernel weight amongst different varieties. Therefore, theoretically after extraction of the oil, which constitutes about $50 \%$ of the weight of the kernel, protein contents must double in almond cake / meal. Indeed, protein content of the analysed almond meals from the three cropyears (Table 3 ) ranges between a minimum of $31.15 \%$ for (FNB-CY2) and $43.24 \%$ for (M-CY1). Similar values have been reported by Rabadan et al. (2017) [20] for almond meals of Ferragnes $(40.50 \%)$ and Ferraduel $(44.85 \%)$ varieties, but a high protein content (55.93\%) for almond meal of Marcona, which is known for its low oil richness.

ANOVA test (Table 4) shows a significant difference between the analysed almond meal samples. The significant differences observed seem to be due to both the genetic factor (almond variety) and the environment (crop year) with significant effects respectively at $P<0.01$ and at $P<0.001$, whereas the factor "Crop Year * Variety" interaction present a highly significant effect at $P<0.001$.

Amino acid (AA)profiles ofanalysed almond cake / mealarepresented in Table 5. Quantitative and qualitative analysis of AA profiles allows the identification of 17AA. The observed AA profiles of almond mealsare dominated by glutamic acid (Glu), aspartic acid (Asp), and arginine (Arg). Respectively,Glu, Asp and Arg contents (\% DM) range between a minimum -maximum values of $8.46 \%$ for (FNB-CY1) - $13.20 \%$ for (M-CY1), $4.25 \%$ for (FF- CY1) - $5.70 \%$ for (M- CY2) and $3.82 \%$ for (FNB- CY2) $-5.31 \%$ for (M-CY2) (Table4). However, cysteine (Cys: $0.01-0.22 \%$ DM) and methionine (Met: $0.23-0.35 \%$ DM) have the lowest contents. Regarding the essential amino acids (EAA), leucine (Leu)is the most abundant, followed by valine (Val). Finally, from a qualitative point of view, registered compositions for AA profiles of analysed almond cakes are in agreement with the finding reported by Sociasi Company et al (2008) [3]. Moreover, from these results, we 
conclude that the genotype (almond variety) strongly influences the quality (AA profiles) and the protein richness of almond seeds and consequently those of almond's oil cakes.

Table 5. Amino acid profiles (Composition \% of crude protein) of almond oil cake of five most cultivated varieties in eastern Morocco (M: Marcona: FNB: Fournat de Breznaud; FF: FerragnesFerraduel, B: Beldi).Analyses for Almonds of three consecutive crop years (CY)

\begin{tabular}{|c|c|c|c|c|c|c|c|c|c|c|c|c|}
\hline & \multicolumn{4}{|c|}{ CY1 } & \multicolumn{4}{|c|}{ CY2 } & \multicolumn{4}{|c|}{ CY3 } \\
\hline & $\mathbf{M}$ & FNB & FF & B & $\mathbf{M}$ & FNB & FF & B & $\mathbf{M}$ & FNB & FF & B \\
\hline Asp & 4.50 & 4.32 & 4.25 & 4.35 & 5.70 & 4.36 & 4.79 & 5.22 & 4.78 & 4.70 & 5.09 & 5.02 \\
\hline Thr & 1.40 & 1.35 & 1.34 & 1.34 & 1.62 & 1.43 & 1.38 & 1.45 & 1.32 & 1.39 & 1.50 & 1.41 \\
\hline Ser & 1.80 & 1.73 & 1.69 & 1.71 & 2.42 & 1.98 & 2.08 & 2.20 & 1.92 & 1.94 & 2.14 & 1.98 \\
\hline Glu & 8.86 & 8.46 & 8.49 & 8.63 & 13.20 & 9.74 & 11.06 & 11.81 & 10.58 & 10.44 & 11.21 & 10.10 \\
\hline Pro & 1.63 & 1.56 & 1.57 & 1.51 & 2.10 & 1.66 & 1.74 & 1.98 & 1.82 & 1.79 & 2.01 & 1.93 \\
\hline Gly & 2.53 & 2.40 & 2.43 & 2.42 & 3.30 & 2.75 & 2.76 & 2.88 & 2.66 & 2.77 & 2.87 & 2.78 \\
\hline Ala & 1.91 & 1.86 & 1.81 & 1.83 & 2.43 & 1.96 & 1.98 & 2.18 & 1.90 & 1.92 & 2.13 & 1.99 \\
\hline Cys & 0.10 & 0.12 & 0.07 & 0.07 & 0.03 & - & - & 0.01 & 0.07 & 0.06 & 0.22 & 0.02 \\
\hline Val & 2.48 & 2.38 & 2.35 & 2.39 & 2.07 & 1.73 & 1.75 & 1.93 & 2.10 & 2.18 & 2.42 & 2.30 \\
\hline Met & 0.23 & 0.30 & 0.32 & 0.24 & 0.23 & 0.26 & 0.24 & 0.23 & 0.27 & 0.32 & 0.35 & 0.26 \\
\hline Ile & 1.94 & 1.89 & 1.84 & 1.83 & 1.66 & 1.34 & 1.39 & 1.48 & 1.65 & 1.68 & 1.84 & 1.73 \\
\hline Leu & 3.19 & 3.07 & 3.02 & 3.03 & 3.47 & 2.80 & 2.91 & 3.18 & 3.08 & 3.09 & 3.45 & 3.20 \\
\hline Tyr & 1.47 & 1.39 & 1.37 & 1.38 & 1.40 & 1.14 & 1.16 & 1.29 & 1.30 & 1.26 & 1.46 & 1.34 \\
\hline Phe & 2.45 & 2.37 & 2.30 & 2.31 & 2.56 & 2.04 & 2.14 & 2.27 & 2.29 & 2.30 & 2.47 & 2.28 \\
\hline His & 1.42 & 1.38 & 1.35 & 1.35 & 1.42 & 1.11 & 1.19 & 1.24 & 1.40 & 1.40 & 1.50 & 1.37 \\
\hline Lys & 1.42 & 1.41 & 1.43 & 1.40 & 1.55 & 1.52 & 1.38 & 1.40 & 1.36 & 1.57 & 1.58 & 1.48 \\
\hline Arg & 4.55 & 4.36 & 4.24 & 4.27 & 5.31 & 3.82 & 4.48 & 4.76 & 4.79 & 4.56 & 5.03 & 4.57 \\
\hline
\end{tabular}

From a nutritional point of view, the analysed almond meal samples show interesting protein values and a medium to pretty good amino acid profile, which is deficient in certain essential amino acids. This finding is in agreement with the results reported by Ahrens et al (2005) [16]. The mean values of chemical indices (CI) and PDCAAS (Proteins Digestibility of Corrected Amino Acid Score) are shown in Table 6. Like all vegetable proteins, which often have one or more limiting amino acids, the analysed samples of almond cakes have relatively low chemical indices $(\mathrm{CI})$, which vary between a minimum of $28.22 \%$ for (MCY2) and a maximum value of $70.81 \%$ (FF-CY3). These "CI" values are comparable to those of proteins of vegetable origin and which are generally lower than the CI of proteins of animal origin. The gap between CI values may be due to the genetic and environmental factors, which strongly influence the amino acid profiles in plants [11].All the calculated PDCAAS values for the analysed samples of almond meals are less than 100 but close to reported values for proteins of maize, rice and wheat [21]. "PDCAAS values" for almond meals range between $24.78 \%$ for (M-CY2) and $62.17 \%$ for (FF-CY3). Besides, for whole almonds,Boye et al (2012) [21], published PDCAAS values for three almond varieties (Carmel, Mission, and Nonpareil) range between 22 and $24 \%$ and are lower than PDCCAS values for almond oil cakes of the five studied varieties (M: Marcona; FNB: Fournat de Breznaud; FF: Ferragnes-Ferraduel; B: Beldi). These differences could be explained by genetic and environmental factors.

Finally, we concluded that almond meal coproducts are interesting sources of essential amino acids (EAA, Table 6). They are therefore new good sustainable nutritional alternatives to animal proteins.

Table 6. Total essential Amino acids ( $\mathrm{EAAA}$ g\%); non-essential Amino acids ( $\Sigma$ NEAA $\mathrm{g} \%$ ); chemical index $(\mathrm{CI})$, and protein digestibility corrected amino acid score (PDCAAS) 
for almond meal coproducts of five studied almond varieties (M: Marcona; FNB: Fournat de Breznaud; FF: Ferragnes-Ferraduel, B: Beldi)

\begin{tabular}{|l|l|l|l|l|}
\hline & $\Sigma N E A A$ & $\Sigma$ EAA & CI $_{(\text {Met }+ \text { Cys })}$ & $\begin{array}{l}\text { PDCAAS (\%) } \\
(\text { Met }+ \text { Cys })\end{array}$ \\
\hline M- CY1 & $25.76 \pm 0.56$ & $16.10 \pm 0.12$ & $47.58 \pm 7.95$ & $41.78 \pm 6.98$ \\
\hline FNB- CY1 & $24.69 \pm 0.16$ & $15.66 \pm 0.10$ & $60.06 \pm 0.78$ & $52.74 \pm 0.68$ \\
\hline FF- CY1 & $24.47 \pm 0.71$ & $15.40 \pm 0.38$ & $58.50 \pm 0.25$ & $51.37 \pm 0.22$ \\
\hline B- CY1 & $24.72 \pm 0.13$ & $15.34 \pm 0.08$ & $44.65 \pm 1.56$ & $39.20 \pm 1.37$ \\
\hline M- CY2 & $34.47 \pm 0.45$ & $16.00 \pm 0.24$ & $28.22 \pm 3.59$ & $24.78 \pm 3.15$ \\
\hline FNB- CY2 & $26.27 \pm 0.08$ & $13.37 \pm 0.08$ & $38.42 \pm 4.75$ & $33.74 \pm 4.17$ \\
\hline FF- CY2 & $28.90 \pm 0.19$ & $13.53 \pm 0.07$ & $32.86 \pm 1.71$ & $28.85 \pm 1.50$ \\
\hline B- CY2 & $31.03 \pm 0.10$ & $14.47 \pm 0.11$ & $30.49 \pm 1.12$ & $26.77 \pm 0.99$ \\
\hline M- CY3 & $28.45 \pm 0.17$ & $14.82 \pm 0.09$ & $45.37 \pm 1.43$ & $39.84 \pm 1.26$ \\
\hline FN- CY3 & $28.13 \pm 0.19$ & $15.24 \pm 0.04$ & $51.40 \pm 2.94$ & $45.13 \pm 2.58$ \\
\hline FF- CY3 & $30.48 \pm 0.87$ & $16.79 \pm 0.56$ & $70.81 \pm 10.12$ & $62.17 \pm 8.89$ \\
\hline B- CY3 & $28.37 \pm 0.24$ & $15.39 \pm 0.10$ & $37.24 \pm 0.29$ & $32.70 \pm 0.26$ \\
\cline { 1 - 2 } True faecal digestibility $(\%)$ & 87.81 & & \\
\cline { 1 - 3 } & & & &
\end{tabular}

\section{Conclusion}

This study focused on the characteristics of oil cake as an extraction residue from almond oils and showed, in view of their major constituents (sugars, proteins, fibres, and minerals), that they can be used as an ingredient or food additive, therefore, with an economic advantage for producers, but also from a zero-waste perspective of great environmental interest.

Although this research was more oriented to almonds harvesting and post-harvesting processing stages, the impact of the genotype and the crop year effect, seem very visible, since the quality of the harvest almonds and their coproducts differ from year to year. This depends on the impact of agricultural conditions and interactions between almond varietiesand pedo-climatic factors. Thus, for the studied oilcake samples of different almond varieties and except their fibre contents, significant differences were observed for all the other analysed parameters (Residual oil, Dry matter, Sugars, Proteins, Ash).

The chemical composition, of the residues of mechanically pressed almond oil (almond meal), depends mainly on the variety of almond that, in turn, is affected by soil and climatic conditions, which determines the quality of the raw material used for the almond oil extraction.

Moreover, the almond meal coproducts contain beneficial nutrients and bioactive molecules; they constitute an interesting source of protein (EAA), dietary fibres and minerals; they have also the advantage to be a gluten-free product. Therefore, these coproducts of almond oil extraction would be an interesting ingredient for specific gluten-free culinary preparations and in the formulation of light foodstuffs. Indeed, world protein demand is growing strongly and it seems necessary to offer new sustainable and good nutritional alternatives to animal protein. Legume cakes, such as soybean and rapeseed meals, because of their relatively balanced essential amino acid profile (EAA), are widely used in the formulation of animal feed and vegan food. Almond oil cakes, despite their relatively unbalanced essential amino acid (EAA) profile, have the advantage of being 
gluten-free and could be a new ingredient for the formulation of new light foodstuffs and vegan foods.

Acknowledgements -We are grateful for the Moroccan Higher Education Ministry and Wallonia Brussels International (WBI Project 2-4) for supporting this research.The assistance of PRODIGIA Company for the mechanical extraction of almond oils and the almond growers in eastern morocco for providing the almond samples for this study.

\section{References}

1. C. Grasselly. CIHEAM, Options Méditerranéennes., 28- 43, 32 (1976).

2. A. J. Esfahlana, R. Jameia, R. J. Esfahlan. Food. Chem.,349-360,120 (2010)

3. R. Sociasi Company, O. Kodad, J.M. Alonso and T.M. Gradziel. Almond Quality: A Breeding Perspective, in J. Janick (Eds.), Horticultural Reviews, New York, (2008).

4. A.Elamrani, R.Melhaoui, N.Houmy, M. Addi, M.Abid, A.Mihamou, M.L.Fauconnier, M.Sindic\& H.Serghini-Caid. Valorisation Challenges to Almonds and their Coproducts: Characterization of Oils Extracted from Broken Almonds Springing from Shelling and Sorting Operations.In proceeding of the fourth American Moroccan Agricultural Sciences Conference, 9-11May 2018, Meknes, Morocco (2018).

5. ISO 662. International Organisation of Standardisation. Corps gras d'origines animale et végétale - Détermination de la teneur en eau et en matières volatiles (1998)

6. C.S. James. Analytical Chemistry of Foods: Determination of fat by the Soxhlet methods. Blackie Academic and Professional, ed., C.S. James, London, (1995).

7. State standard of Russian Federation GOST5672-68. Method for determining the mass fraction of sugar. Bread and bakery products. (1968)

8. A.O.A.C. 991. 43. Association of Official Analytical Chemists: Total, Soluble, and Insoluble Dietary Fibre in Foods: Enzymatic-Gravimetric Method, Mes-Tris Buffer (1996).

9. A.A.C.C. 08-01. American Association of Cereal Chemists. Ash: Basic method (2001).

10. A.F.NOR. NF.V04-407. L'Association Française de Normalisation. Détermination de la teneur en azote total et calcul de la teneur en protéines - Méthode Kjeldahl (2002).

11. A. Rabadán, M. Álvarez-Ortí, J.E. Pardo. Sci. Hortic. Amsterdam.,218-224, 244 (2019).

12. D. H. Spackman, W. H. Stein, and Stanford. Anal. Chem., 1190-1206,30, 7 (1958).

13. FAO/WHO/ONU. Food and Agriculture Organisation/ World Health Organization/ Organization of United Nations. Protein and amino acid requirements in human nutrition. Technical Report Series 935. Geneva, Switzerland. (2007).

14. A. Sujak, A. Kotlarz, W. Strobel. Food Chem., 711-719,98 (2006)

15. G. SchaafsmaThe Protein Digestibility-Corrected Amino Acid Score, in Proceedings of the symposium Criteria and Significance of Dietary Protein Sources in Humans, 4 October 1999, San Francisco, USA (1999).

16. S. Ahrens, M. Venkatachalam, A. M. Mistry, K. Lapsley\& S. K. Sathe. Plant. Food. Hum. Nutr., 123-128,60 (2005).

17. R. Arbouche,Incorporation du tourteau d'amande d'abricot en substitution au tourteau de soja dans l'alimentation des animaux domestiques: Ruminants (cas des ovins à l'engrais) et des monogastriques (cas du poulet de chair).Doctoral Thesis,ElHadj Lakhdar University, Batna, Algeria (2013).

18. S. Ramachandran, S. K. Singh, C. Larroche,C. R. Soccol, A. Pande. Bioresource. Technol.,2000-2009, 98 (2007)

19. S. Sivaramakrishnan\& D. Gangadharan. Chapter 13: Edible Oil Cakes. Biotechnology Division, National Institute for Interdisciplinary Science and Technology (NIIST), CSIR, Trivandrum 695 019, Kerala, India (2009). 
20. A. Rabadán, M. Álvarez-Ortí, R. Gómez, A. Pardo-Giménez, J. E. Pardo. Sci. Hortic. Amsterdam., 539-546,225 (2017).

21. R. Savoire, J.L. Lanoisellé, E. Vorobiev. Food. Bioprocess. Tech., 1-16,6 (2013)

22. D.Tungmunnithum, A. Elamrani, M. Abid, S.Drouet R.Kiani, L.Garros, A.Kabra, M.Addi and C. Hano.Quick, Green and Simple Ultrasound-Assisted Extraction for the Valorization of Antioxidant Phenolic Acids from Moroccan Almond Cold-Pressed Oil Residues, Appl. Sci. 10 (2020).

23. D.Tungmunnithum, M. Abid, A.Elamrani, S.Drouet, M.Addi and C.Hano. Life.10 (2020).

24. S. Karaman, S. Karasu,F.Tornuk, O.Toker, U.Geçgel, O. Sagdic. J.Agr. Food. Chem., 2305-2313,63(2015).

25. S. Čolić, G. Zec, M.Natić, and M.Fotirić-Akšić. Almond (Prunus dulcis) oil, in e-book "Fruit Oils: Chemistry and Functionality". M. F. Ramadan Editor (Springer Nature Switzerland, AG 2019).

26. J. Boye, R. Wijesinha-Bettoni and B. Burlingame. Brit. J. Nutr., S183-S211, 108 (2012). 